\title{
Hviezdoslavova baladická tvorba
}

\section{Ján Gbúr}

\author{
GBÚR, J.: Hviezdoslav's Ballads
}

SLOVENSKÁ LITERATÚRA, vol. 68, 2021, no. 6, pp. 614-630

DOI: https://doi.org/10.31577/slovlit.2021.68.6.3

ORCID ID: 0000-0003-4032-6382

\author{
Key words: Pavol Országh \\ Hviezdoslav, ballad, Realism, \\ interpretation, themes, expressive \\ means
}

The article concentrates on interpreting Pavol Országh Hviezdoslav's (1849-1921) ballads - the part of his oeuvre which has only been investigated marginally so far. His ballads from the late 19th and early 2oth centuries (U kaplice [At the chapel], Zuzanka Hraškovie [Zuzanka Hraškovie], Anča [Anča], Margita [Margita], Studnica [The well], Smelá Katka [Daring Katka], Topel'ci [Drowned], Jedlica [Fir tree], Krivoprísažník [False witness], Mladá vdova [Young widow], Matúš Stolár [Matúš Carpenter]) adapt some of the traditional themes of folk and Romantic ballads (crime and punishment, moral failure, folk customs), but also bring new motives (the search for the spiritual path from pragmatic truth criteria, property disputes and unorthodox solutions to life problems, social and economic disparity and its effects). Comparison of Hviezdoslav's ballads with those written by Slovak poets of the Romantic period Janko Král' and Ján Botto shows his authentic realist attitude in the handling of the genre. Hviezdoslav accentuated the epical side of the narratives, employing several means of representation (on the level of the narrator and on the level of the structure of the stanza and verse). $\mathrm{He}$ realised the lyrical side of the narratives, their balladic atmosphere - also through the functional structure of the verse - but primarily through expressive, lyrical depictions and commentaries. 

zdôveril priatel'ovi Jozefovi Škultétymu: „Privykám - veru tažko! [...] Nenachodím sa, prelomenú vidím celú svoju duševnú činnost'; som znechutený, znevolnený. - Avšak dá Boh, že čo aj po drahnom čase, predsa len prídem k sebe, prinavráti sa mi stratený pokoj duše, bez ktorého ozaj nestojím za nič. To prekliate moje citlivkárstvo! To bude príčinou všetkého..." (Korešpondencia P. O. Hviezdoslava so Svetozárom Hurbanom Vajanským a Jozefom Škultétym 1962: 148).

Svoj vnútorný nepokoj a melancholické stavy sa usiloval, hoci i s tažkost́ami, prekonat' najmä literárnymi aktivitami: „nútim sa do práce denne, nejde to" (Korešpondencia... 1962: 148). V jarných mesiacoch roku 1900 sa postupne v zmenenom prostredí ako-tak udomácnil, čoho dôkazom je zintenzívnená spolupráca s J. Škultétym na dokončení tretieho zväzku Zobraných spisov básnických, do ktorého poslal pät' starších prác, všetko z oblasti biblickej poézie: Po 5o-tich rokoch, Agar, Kain, Ráchel, Vianoce (Korešpondencia... 1962:151-152). Z novej, ako zdôrazňoval, „skúpej“ a ,jalovej“ tvorby poslal Škultétymu biblickú báseň Sen Šalamúnov (Korešpondencia... 1962: 152), s informáciou, že by do tretieho zväzku rád poslal „niekol'ko kúskov z kratšej epiky“ (Korešpondencia... 1962: 152), a zároveň s podmienkou, aby boli najprv publikované v časopise Slovenské pohl'ady. Ked' poslal prvú z týchto básní, v samotnom liste naznačil jej názov iba slovom „bubrovskom“ (je súčast'ou prvého verša balady U kaplice: „Na bubrovskom poli, kde ten vŕštek holý"), no v poznámke na konci listu už jej titul uviedol: „Nad básničkou U kaplice daj snád' ešte nadpisom: Z kratšej epiky № 1, bo ich azda bude viac“ (Korešpondencia... 1962: 152). Zároveň dodal: „No nečakaj dáku araňovskú baladu, vidím, dač takého nenapíšem nikdy. Darmo, ako viem, tak píšem. A nevedel bys' dajakých témat k podobnému spracovaniu? Vel'mi by si mi pomohol“" (Korešpondencia... 1962: 152).

Hviezdoslav teda ponúkol Škultétymu baladu, žáner v tom čase stále živý a čitatel'sky žiadaný, ktorému sa venovali viacerí romantickí, ale aj realistickí tvorcovia literatúry, vrátane Svetozára Hurbana Vajanského. ${ }^{1} \mathrm{Z}$ jeho formulácie zároveň vyplýva, že baladický žáner dobre poznal, a to nielen z domácej ludovej a romantickej tvorby (Janko Král', Ján Botto), ale aj zo zahraničnej romantickej literatúry, konkrétne mad'arskej. Rovnako však poznal nemeckú baladickú tvorbu, napokon, sám preložil niekol'ko Goetheho balád (Mignon, Spevec, Rybár, Poklado-kop). ${ }^{2}$ Osobitne treba upozornit' na českú baladickú tradíciu, ${ }^{3}$ ktorú Hviezdoslav mohol mat' zažitú prostredníctvom baladickej tvorby jemu typologicky blízkych autorov Vítězslava Hálka, Jana Nerudu a Jaroslava Vrchlického.

1 Analýze Hviezdoslavovej baladickej tvorby sa doterajší výskum básnikovho diela venoval len sporadicky. Okrem literárnohistorických portrétov básnika, v ktorých táto téma bola okrajovou čast'ou hodnotení jeho literárnych aktivít, osobitne treba upozornit' na štúdiu Viliama Turčányho interpretujúcu niektoré Hviezdoslavove balady v kontexte autorovej kratšej epiky z ludového a zo spoločenského prostredia (Turčány 1963: 193-251).

2 Publikované pod spoločným názvom Z ballád Götheových, 1901. Slovenské pohl'ady, roč. 21, č. 4, s. 180-183. V sprievodnom liste J. Škultétymu Hviezdoslav písal: „Pripojene posielam Ti preložené 4 balady Goetheove čo príspevok pre aprílové číslo; vari sa Ti zídu“ (Korešpondencia... 1962: 165, 337).

3 K téme českej baladickej tradície podrobnejšie Tureček 2012; Mocná 2012. 

v liste, sa dá predpokladat', že Hviezdoslava zaujali najviac jeho historické balady (Waleskí bardi, Dve Szondiho pážatá...), pretože je v nich zobrazená romantická ideová cesta nacionálnych vodcov brániacich si svoju morálnu integritu a autentické (slobodné, rytierske, národné) bytie aj za cenu straty života. Je však pochopitelné, že Hviezdoslav nesmeroval k „araňovskej balade“: jednak bol už zrelý básnik s vyhraneným autentickým rukopisom, jednak nemal aranyovskú nekompromisnú povahu. Na rozdiel od mad'arského romantika neodmietal ideový alebo existenciálny kompromis, pretože ako citlivý pozorovatel' reálneho sveta videl v ňom možnost' riešenia osobnej, rodinnej alebo národnej traumy. Nepriamym dôkazom jeho povahovej črty je aj výrok z vyššie citovaného listu: „To prekliate moje citlivkárstvo!“ (Korešpondencia... 1962: 148).

Hviezdoslav mal ambíciu tvorit' balady vlastnou zobrazovacou metódou. Vel'mi rýchlo sa zorientoval v poetike baladického žánru, osvojil si konštantné i variantné znaky l'udovej a romantickej balady. Jeho zámerom bolo vytvorit' taký typ baladického žánru, v ktorom by prepojil vlastnosti tradičnej baladickej štruktúry, zvlášt jej romantickej verzie, s vlastným básnickým rukopisom a videním sveta. K tvorivému prístupu k baladickým sujetom, k ich výraznej modifikácii a inovácii, mu pomohli podnety literárneho charakteru (stabilná literárna životnost' žánru balady, domáce a inonárodné podnety romantickej baladickej tvorby, dlhodobá recidíva romantickej poetiky v jeho tvorbe) a takisto impulzy mimoliterárnej povahy, najmä nepriaznivé národné a sociálne pomery charakteristické pre „,̌as dlhého pôstu, čas žaloby a bolestenia“, ako dobovú situáciu sám charakterizoval (Korešpondencia... 1962: 154-155). Svoju rolu iste zohral aj básnikov depresívny životný pocit na konci 19. storočia, ktorý vyplynul z jeho už spomínanej komplikovanej osobnej adaptácie na nové pracovné a životné prostredie.

Pri práci s novým žánrom Hviezdoslav pocitoval ako problém hl'adanie nekonvenčných príbehov, v ktorých by dominovali revoltujúci hrdinovia nedobrovol'ne znášajúci svoj osud, ludské a sociálne utrpenie. Požiadal preto J. Škultétyho o pomoc pri hl'adaní „dajakých témat“, na čo mu Škultéty odporučil Čaplovičovu „bibliotéku“ ${ }^{4}$ v ktorej by mohol nájst' niekol'ko zaujímavých podnetov z oblasti slovenských „historických i nehistorických“ povestí (Korešpondencia... 1962: 153-154). Väčšina z námetov, ktoré Hviezdoslav spracoval vo svojich jedenástich baladách (U kaplice, Zuzanka Hraškovie, Anča, Margita, Studnica, Smelá Katka, Topel'ci, Jedlica, Krivoprísažník, Mladá vdova, Matúš Stolár), je ukotvená v reálnej látkovej skutočnosti, v ktorej sa odohrávajú životné osudy jednotlivcov poznačených rozličným typom problémovosti: hl'adanie spirituálnej cesty z pragmatických kritérií pravdy, utrpenie a znášanie trestu za previnenie, porušenie tradíciou udržiavaných kolektívnych pravidiel v rurálnom prostredí, vžitý spôsob myslenia bez racionálneho zdôvodnenia, pýcha a jej dôsledky, majetkové spory a ich dôsledky, sociálny rozpor „chalupa - kaštiel'“ realizovaný na individuálnej rovine.

Tvorivá skúsenost' s realistickou zobrazovacou metódou bola pre básnika dôležitá v tom, že v značnej miere odromantizovala jeho baladické sujety.

4 Škultéty mal na mysli Čaplovičovu historickú knižnicu s bohatým zbierkovým fondom, pomenovanú podla svojho zakladatel'a Vavrinca Čaploviča (1778 - 1853), významného zberatela kníh, dnes súčast' Oravského múzea P. O. Hviezdoslava. 
Dôkazom je už prvá publikovaná balada U kaplice (Hviezdoslav 190ob: 401-402). ${ }^{5}$ V príbehu má osobitnú úlohu motív kňazského povolania, ktorý je ojedinelý v slovenskej literatúre, zvlášt' v baladickej literatúre romantického a realistického obdobia. Priestorovo je dej balady koncentrovaný na „bobrovskom poli“, ${ }^{6}$ na ktorom stojí „pustá, ošarpaná:preds’ útulná schrana“ - „kaplica“.7 V nej sa nachádza „obraz“ so známym výjavom sedembolestnej Panny Márie držiacej v náručí svojho Syna. Tento v slovenskom krestanskom spoločenstve uctievaný obraz Matky - patrónky, ochrankyne, orodovnice a pomocnice národa a vlasti a Matky bolesti - Hviezdoslav zapracoval do textu balady ako jeho významovo tažiskový bod. Pomerne vel'ký epický priestor vyčlenil postave neštastnej zbožnej ženy-matky, ktorá príchodom ku kaplnke predznačila svoju vnútornú bolest' súvisiacu s tragickými osudmi svojich troch synov.

Smrt' prvých dvoch synov úzko súvisí s rizikami ich povolaní. Syn plátenník-kupec zomiera v lese rukou „zbojca“ pri nočnej preprave tovaru. Druhý syn - vojak bol smrtel'ne zranený na bojisku pri obrane svojej „otčiny“. Strata tretieho syna - kňaza nie je spojená s jeho fyzickou stratou. Kým prvému a druhému synovi bol život vzatý, tretí ho daroval dobrovol'ne. Zriekol sa legitímnej lásky k vlastnej rodine z lásky ku Kristovi, k prežívaniu tajomstiev Premeny, ku ktorej dochádza počas svätej omše pri sviatosti Eucharistie: „Svätú omšu slúžil: v svätotaj sa hrúžil, / hl'adal k jadru prielom... / Pozdvihol i dopil: tela oči sklopil, / prezrel duchom, vnikol: spojil sa, jaktúžil, / s Kristom Spasitelom -/.“ Podstatou kňazskej služby je milovat' Božie spoločenstvo Božím spôsobom - darovaním vlastného života pre službu Božej Pravde. Podla teológa Antona Fabiana kňaz opakuje len to, „,̌̌o spravil Ježiš: z ukrižovania urobil premenenie, teda dobrovol'né darovanie sa" (Fabian - Chalupa 2016: 299).

Z pohl'adu postavy matky strata detí prináša vel'kú duševnú bolest' (,Jak mi srdce krája!"). Strata tretieho syna má iný rozmer. Matka kňaza ide k obrazu sedembolestnej Matky Ježiša, aby sa nielen posilnila vo viere v duchu evanjelia, ale aby prijala a pochopila jej bolesti vzhl'adom $\mathrm{k}$ tomu, čo sama prežila ako matka klačiaca pri nohách ukrižovaného syna („Tvoja strata zvládla; / ratuj, božská mati!“).

Kompozične a významovo sa balada uzatvára záverečnou strofou, ktorá je takmer totožná s tret'ou strofou básne. Posledný verš („vtáčik zapisknutim“) však prezrádza, že oproti poslednému veršu tretej strofy (,Jak inakšie predtým!“) je v nej značný významový posun, ktorý sa viaže na motív zarastajúceho chodníka ku „kaplici“. ${ }^{8}$ Hviezdoslav v tomto obraze otvoril tému spirituálnej potreby pre

5 Citáty z balady sú z edície Hviezdoslav 1948a: 144-146.

6 „Bobrovské pole“ je synekdochické pomenovanie konkrétneho miesta v hornooravskej obci Bobrov blízko Námestova. Ide o kopec nad obcou, na ktorej bola roku 1843 postavená kaplnka Nanebovzatej Panny Márie, pričom koncom 19. storočia bobrovský rodák, kanonik Štefan Koštialik, dal od kostola ku kaplnke postavit štrnást' zastavení krížovej cesty. Od roku 1894, po jej vysviacke, sa tu pravidelne konajú bobrovské „odpusty“ na sviatok Nanebovzatia Panny Márie. Hviezdoslavova balada priamo súvisí so symbolikou tohto miesta. Bližšie História kalvárie. Dostupné online: https://www.farabobrov.sk/kalvaria/ historia-kalvarie/

7 „Kaplica“ je oravský nárečový výraz pre kaplnku, malú sakrálnu stavbu s duchovnou a pietnou funkciou, situovanou v chotári, na krížnych cestách, pri vstupoch do obce, na cintorínoch a podobne.

8 Pri záverečnej korektúre textu pred publikovaním balady v časopise Slovenské pohl'ady Hviezdoslav vo verši nahradil slovo „prútim“výrazom „kvietim“, čím potvrdil významový rozmer z tretej strofy (Hviezdoslav 1956: 455). 
spoločenstvo veriacich, ktorých život zasiahla predmetnost'. Spirituálny rozmer balady podporil aj niektorými formovými prvkami, najviditel'nejšie v strofickom a vo veršovom pôdoryse. $\mathrm{V}$ básni využil $\mathrm{v}$ romantizme najpoužívanejší dvanást'slabičný verš, ktorý skombinoval so šest'slabičným veršom. Tradične romantický je aj použitý striedavý rým (abab) a takzvaný vnútorný rým.

Básnické úsilie uchopit transcendentno sa u Hviezdoslava vždy spájalo $\mathrm{s}$ Božím Princípom. Prostredníctvom neho sa usiloval uchopit problémovú realitu sveta, osobitne sveta dediny, jeho civilizačné defekty, zakorenenost' v konvenčných kultúrnych stereotypoch, ale aj to, ako uchopit' priestor pre hrdinov vyrovnávajúcich sa s touto realitou. $\mathrm{V}$ príbehu balady $U$ kaplice výrazne načrtol svoj „dotyk“ so spirituálnym svetom, s jeho duchovne uzdravujúcou funkciou. V d'alších baladách (Jano Gorazda, Topel'ci, Krivoprísažník, Smelá Katka, Studnica, Jedlica) využil iracionálne predstavy a tajuplné postavy zo záhrobia na otváranie reálnych problémov dedinského života.

Motívy posmrtného života, kostlivcov a mumifikovaných tiel sa často objavujú v umeleckej literatúre, svetovej aj slovenskej. Do svojej baladickej tvorby ich vniesol aj Hviezdoslav (Krivoprísažník, Topel'ci, Pomsta mŕtvych, Smelá Katka), pričom ich funkčnost' prehodnocoval na príbehoch tematicky ukotvených v slovenskej rurálnej skutočnosti.

V balade Krivoprísažník rozvinul príbeh krestana a váženého „chýrneho" richtára, ktorý za svoje hriešne previnenie (vedome zhrešil, ked' ako richtár pod vplyvom svojej ženy zemianskeho pôvodu krivo prisahal proti chudobnej rodine, ktorá sa dožadovala potvrdenia vlastníctva pôdy) proti najvyšším Božím zákonom (druhému a ôsmemu Božiemu prikázaniu), dostane primeraný trest („posvätná zem“ neprijme rakvu s jeho telom, preto ako „kostlivec“ s troma zdvihnutými prstami nad lebkou je vystavený $\mathrm{v}$ kúte kostola na výstrahu pred hriešnymi činmi krestanov). ${ }^{9}$ Iracionálny prvok autor umiestnil do záveru balady. Rozprávač opisuje situáciu, ked' richtárova dcéra Eva sadí kvety na otcov hrob. Všimne si, že hoci ich polieva, stále vädnú. $\mathrm{V}$,jeden deň však - úžasom až stuhla - / na povrchu, tuliti! I-truhla...". Prekvapení dedinčania truhlu s neštastným richtárom pochovajú do zeme ešte raz, prikryjú ju tažkým kameňom, aby sa tento neprirodzený a racionálne nevysvetlitelný úkaz už nemohol zopakovat'. Nadzemská sila je však silnejšia ako racionálny úsudok živých: rakva s rozkladajúcim sa telom „krivoprísažníka“ sa objavuje na jeho hrobe niekol'ko rokov po sebe. Vždy ked'sa tak stane, farníci vykonajú pohrebný rituál: „Div sa počne: / schvie sa hrob... prásk! Balvan v mrvín sprchu, / s mŕtvolou zas rakev - na povrchu! [...] A tak sa to opakuje roky." Až raz zem „vyvrhne“ na hrob kostlivca. „Čo s nim??" pýta sa rozprávač a vzápätí odpovedá: „Rady neznali si l'udia. / Až im vnuklo: zem je príkrov boží, / ako hviezdy - len tým prítulku dá, / ktorí z pravej cesty nezablúdia... / Iba, kde čo človek zlepi-zloží, / tak akjesto / zadné miesto / suchým hnátom-krivoprísažníka- / Tak sa dostal pod chór-do kútika..."

Osobitost' d'alšieho baladického príbehu Pomsta mŕtvych spočíva v tom, že sociálne vydel'ovanie bohatých ludí v dedinskom prostredí prekračuje hranice záhrobného života. ${ }^{10}$ Hviezdoslav týmto príbehom „odklial“ poverovú tradíciu 
o „nehýbaní s mŕtvymi“ na cintoríne. Fiktívnu látku preniesol do fantazijného

sveta, v ktorom spojil realitu s irealitou natol'ko, že činnost' „,kostlivcov“, ich realisticky zobrazené nočné búranie stavby mohyly pre „boháča“, ktorá mala stát' na mieste ich večného spočinutia, možno s určitou dávkou predstavivosti vnímat'ako protestnú pracovnú aktivitu chudobných mŕtvych, ktorých živí (,palier“ a stavitelia boháčovej „mohyly“) ponížili tým, že ich kostry nahádzali k plotu cintorína ako niečo nečisté, nehodnotné a nehodné úcty.

V balade Topel'ci, ktorú V. Turčány označil za Hviezdoslavovu najfantastickejšiu baladu (Turčány 1963: 204), prehodnotil tradičnú baladickú romantickú koncepciu v tom zmysle, že v nej nevytvoril priestor pre aktívnu, vnútorne silnú, po slobode túžiacu, ale okolím nepochopenú osobnost', ktorej život sa podla baladických žánrových zákonitostí končí tragicky. ${ }^{11}$ Konfliktný zápas medzi prirodzenost'ou života a absurdno-iracionálnym priestorom predstavivosti, ktoré bolo v tradičných baladických sujetoch živené ludovými povestami a legendami, sa v tejto balade ruší. Postavy zo záhrobného sveta sa stretnú s postavami z reálneho sveta, aby si v bujarej zábave potvrdili blízkost' obidvoch svetov, prirodzený kolorit života a smrti. Za túto prirodzenost' už nemusí nikto obetovat' svoj život. Príbeh s tragickým koncom môže vystriedat' príbeh s parodickým koncom, najmä ak jeho „hrdinom“ je postava zo živočíšnej ríše - kohút (Gbúr 2021:32-36).

Autorský rozprávač, ktorý svoje rozprávanie rozvija digresiami (čím spomaluje epické tempo) alebo parentézami (ktoré zas spomalujú epickú naráciu; Matiaška 2001:185-190), načrtne v úvode balady charakteristiku dňa „Na Michala“. Podl'a ludovej pranostiky tento deň patrí predovšetkým oslave plodov rol'níckej práce. Úvodná čast' príbehu je preto priestorovo umiestnená v dedinskej krčme, v ktorej sa v podvečernom čase koná michalská zábava. Rozprávač vstupuje svojou lineárnou naráciou do centra zábavy, pričom jej gradáciu vystaval na piesňovom repertoári („šuchavé a rezké piesne“), položartovných slovných súbojoch mládencov, hádavých dialógoch matiek na tému, ktorá z dievčat je „najkrajšia i najbohatšia“ či ktorá má najkrajšie šaty.

Druhú čast' príbehu vypíňa pohl'ad rozprávača na zábavu utopencov (,topel'cov") s prvkami bizarnosti, ba až morbídnosti. Tí totiž, podl'a miestnej povery, vychádzajú na Michala zo svojho záhrobného vodného sveta v polnočnom čase, aby do prvého zakikiríkania kohúta prežili ,niečo pekné“ zo svojho živého bytia. „Niečo pekné" značí zúčastnit' sa bujarej zábavy, podobnej tej, ktorú možno ako živí ludia prežili počas michalskej noci. Hviezdoslav sa rozhodol zobrazit' priebeh zábavy utopencov realistickým, čiastočne až naturalistickým postupom. Jeho vymyslená, možno vysnívaná, priam surrealistická vízia záhrobia, v jeho tvorbe výnimočná, sa odohráva na ,priepuste“, na jazernej hati, kde podla dedinčanov bývajú duše utopených ludí.

Zábava utopencov začína $\mathrm{v}$ baladicky exponovanom čase - o polnoci pri splne mesiaca. Z vody na breh výpustu vychádza s „čl'apotom“ celé panoptikum „zhynulých tam od topel'cov dávnych, nových“. Svoje „drahé" prehnité „,halieny a plášte“ vešajú na „rakyty“a ,jelše “, aby „uschli“, lebo v nich chcú íst' na svoj michalský ples. Opis príprav kostlivcov na ples vyznieva ako paródia na reálne 
620 plesové zábavy. „Topel'cove“ ženy s „uškieravými“ čelustami a „dutými“ očami si na seba vešajú drahé „čačky“ (náušnice z „chvostálov“, okolo ramien „tlsté pijapani-vydry / či zjej kôry / slákom zo škrupiny: / tidli-pidli! udri-vydri! / šiky-myky! / pre potvory, / neštastlivé pre kaliky-/ Tiny-tany! tany-tiny!"

Záverečná čast' balady je opät priestorovo situovaná do dedinskej krčmy, v ktorej sa odohrá niečo nezvyčajné: tanec živých s mŕtvymi. Všetci prítomní sú v očakávaní príchodu nezvyčajných hostí. Rozprávač dá v tomto emočne vybičovanom čase priestor rozhovoru viacerých mládencov, ktorí prezradia svoj až desivo jednoduchý „prítomnostný“ “životný princíp: „,Kto by tejto noci ležal!?’ /,Iba mŕtvy! Len raz žiješ, / potom zgegneš-v zemi zhniješ-‘,Žime dneska! zajtra mrime... “'Žijú prítomnostou, nerozmýšlajú, čo bude zajtra. Pudovo si uživajú vol'nost', tešia sa na „tančeky“ a zábavu sutopencami. Je polnoc. „Vošli-hrúza! Bled’na líci / u ludí, žas - návštevníci, vyvolaní zjäzu [...] Na nich, na kostlivcov ohlodaných, / čupry-kutle z tráv, a háby / vlásaň, zdobou plazy, žaby, / hady... na strach! Na hnus!... L'udia gánia, zmrzli všetci. / Dievky trnú rikované; / chlapcom osineli skrane, / na smelost' všakneochladli; / hudcom sláky poupadli..."Napriek tomu, že mládencov zaskočil príchod hostí, premohli ostych a, hoci s odporom, hladia smrtným postavám do očných jamiek, do zjazvenej tváre, dotýkajú sa ich mokrých prehnitých handier, počúvajú v tanci hrkanie ich kostí. Absurdné predstavenie v krčme končí. Kostlivci odchádzajú do svojho záhrobného sídla, berú však so sebou dievčatá a mládencov, ktorých matky s plačom bránia: „Nedáme si / dcér, nie!... Idte, odkundesi! / v peklo sami“, „Ani synov spriahat's takou holotinou!..." Baladický príbeh speje k svojej tragicko-parodickej koncovke. Vážnu chvillu vyrieši kohút, ktorý z pôjdu domu oproti krčme zakikiríka. Pre kostlivcov je to signál, aby v „okamženi“ opustili krčmu a „s vytím dutým “ ušli do svojho záhrobného sveta. „Kohútik jaraby““ sa pre dedinčanov stal hrdinom-záchrancom živých. Pre majitel'ku kohúta zase dôvodom na jeho záchranu: „Ako oko si ho strežiem! / nepredám ho, nezarežem [...] Ožit'Vám dal, mne dá vyžit'..."

V textovo najrozsiahlejšej balade Smelá Katka Hviezdoslav spracoval jednu z tém poverových ludových tradícií, ktoré na konci 19. storočia v podmienkach rurálneho prostredia bránili jeho obyvatel'om intenzívnejšie sa otvárat meniacemu sa svetu a pritom zachovávat svoju kultúru. ${ }^{12}$ Niektoré povery vzbudzovali v lud'och neopodstatnené obavy o zdravie seba i rodiny, o stratu štastia a lásky v živote a podobne. Príbeh tejto balady básnik ukotvil v rozšírenej tradícii večerných priadok, kde sa stretávali väčšinou nevydaté dievčatá. Ich súčastou boli aj improvizované zábavy a tance s maskovanými návštevníkmi, množstvo rozmanitých hier a divadelných výstupov v zvieracích či žobravých maskách a podobne. Túto tradíciu využil pred Hviezdoslavom napríklad J. Král'v balade Križ a čiap$k a$, o čom svedčí podobne rozvinutý motív priadok, ale najmä takmer identický 
koncept osobných vlastností hlavných postáv - Mary v Král'ovej balade (nebojácna, racionálne uvažujúca „šelma“) a protagonistky Hviezdoslavovej balady Katky (smelá, otvorená pre rozumné vysvetlenie záhrobných javov). Rozdielne sú iba tragické závery ich životov. Kým Mara zomiera zásahom nadprirodzených síl pre svoje previnenie proti poverovej tradícii (zobrala kríž a čiapku z hrobu mŕtveho), Katka, ktorá riešila podobné previnenie (vzala z hrobového kríža venček), si smrt' spôsobila sama: ked' chcela vstat'z hrobu mŕtveho Kuba, ,galún“ visiaci z jej vrkoča zavadil o kríž. Otočená chrbtom ku krížu nevedela racionálne vyhodnotit' situáciu, zlakla sa, premohol ju mŕtvolný strach z poznania, že hrob nie je len „hruda a skala“, ale že v sebe skrýva ducha zomrelého, to, čomu doteraz racionálne vzdorovala. Sila iracionálneho tajomna jej zastaví srdce, vezme život (,mladú dušu vypustila“). Král'ovu baladu charakterizuje spojenie vecnej naratívnosti so širokou škálou baladických výrazových prostriedkov (Kraus 1966: 178), s dominanciou lyrickej obraznosti. Naopak, Hviezdoslavovu baladu charakterizuje epická šírka daná bezprostrednost'ou zobrazovaného príbehu a spomal'ovaním hlavného deja vedlajšími opismi a reflexiami.

Hviezdoslav skúšal na prelome 19. a 20. storočia vo svojej epickej tvorbe nosnost' romantických postupov v realisticky koncipovaných príbehoch. Príkladom tohto riešenia je aj balada Margita, ktorá nielen názvom, ale aj niektorými postupmi spracovania známej povest'ovej látky pripomína poslednú baladu romantického básnika J. Bottu Margita a Besná.

Základom historickej povesti o skalnom brale pri Strečne nazvanom Margita a Besná je príbeh o láske a žiarlivosti, ktorá spôsobila smrt' dvoch mladých žien: macochy a jej vekovo blízkej nevlastnej dcéry. Hviezdoslav poznal Bottovo spracovanie tejto historickej povesti. Otázne je, prečo sa rozhodol vytvorit' jej vlastnú baladickú verziu. Možno chcel týmto spôsobom ukázat' svoj vztah ku koreňom ludovej slovesnej kultúry a k romantickej tradícii spracúvania jej baladických podnetov, prípadne chcel vyskúšat' nosnost' vlastnej tvorivej metódy pri spracúvaní kanonického námetu z ludovej povestovej tvorby. Porovnaním Bottovho ${ }^{13}$ a Hviezdoslavovho textu ${ }^{14}$ sa dá ukázat' miera Hviezdoslavovho autentického spracovania historickej povesti.

Obidvaja autori zvolili vo svojich baladách rozdielne kompozičné riešenie. J. Botto umiestnil do básne expozičnú a epilógovú čast', pričom obidve časti odlišsil od centrálneho epického príbehu, ktorá sa vyznačuje sedemslabičným veršom a nerovnakou veršovou skladbou v strofách, dvojnásobnou slabičnou dížkou verša (štrnást') a rovnakým počtom veršov v strofách (dvanást'). V expozícii básne dostala priestor informačno-opisná personifikovaná reč „plte“ o ceste dolu Váhom. Do nej vkomponoval rozhovor pltníkov o nebezpečnom úseku riečnej cesty pod skalnými výbežkami Margitou a Besnou a záver strofy ukončil náboženským a národno-optimistickým rozmerom zdolávania prekážok - „prejde Slovák i cez peklo, prejde v božom mene“. Epilóg básne je autorovou úvahou s optimistickým záverom o dôsledkoch „hriechu skamenelom“.

13 Povest'z Považia. V rukopise Zobraných spevov (1879) mala názov Margita. Tak vyšla v časopise Orol, roč. 10, 1879, s. 130-131. J. Botto ju napísal podla povesti zapísanej Alojzom Mednyánszkym v jeho knihe Malerische Reise aufdem Waagflusse in Ungern (1826, 1844).

14 Citáty z balady sú z edície Hviezdoslav 1948a: 99-107. 
Hviezdoslav v básni nepoužil prológ, osobitne vyčlenil iba epilóg, v ktorom „apeloval“ na pltníkov, aby sa opreli vo svojej nebezpečnej práci o Boží princíp a mravnú silu človeka, ktoré majú predpoklady premôct' všetky príkoria ludského sveta, vrátane ich iracionálnych vodcov - „svetlonosov“. Strofa epilógu sa sylabicky ani stroficky nelíši od centrálnej príbehovej časti básne. Má rovnaké sylabicko-strofické charakteristiky: sedemveršová strofa, trochejský veršový rytmus, verše v strofe sú sedem- a osemslabičné. Epická zložka textu je podčiarknutá jednak rýmovou skladbou (abcacba), veršovými presahmi, ktoré tlmia pravidelnost rytmického trochejského veršového podložia, a kombináciou krátkych opisov a opytovacích a zvolacích viet, expresívnych a nárečových výrazov, citosloviec a najmä frekventovaných ,epizeuxových“ viet. Bottov verš má pravidelný sedemslabičný trochej a združený rým, ktorý vytvára pravidelnú a výraznú rytmickú viazanost' na konce veršov.

Hviezdoslav začal tragický príbeh pohladom macochy a „pastorkyne“ z okna ich domu na pekného mladého ,šuráka“, „oberučného čel'adníka“. Z ich krátkeho rozhovoru vyplynie, že macocha ho chce za paholka, pričom nevlastná dcéra jej prezradí, že sa chce ženit' a v nedelu príde $\mathrm{k}$ nim so strýkom. V nedelu predvečerom privíta „šuráka“ Janka a jeho strýka so slovami: „Hybajte dnu pospolu! / Napiekla som, prikryla som, / naložila radostníkom..." Hovorí im o starostiach s gazdovstvom a osloví Janka: „Prijednaj sa - za paholka.“ Čel'adník mlčí, je zaskočený. Mladá gazdiná vycíti príležitost' oslovit' ho ešte zaujímavejšou ponukou: „Chceš byt' viacej? - Hádam... gazda až...?“ Strýko vidí príležitost' zmenit' sociálny status svojho synovca, preto mu dohovára: „Však pováž, synku: / chudobný si! - Také śtastie - [...] Prvý gazda!" Mládenec rozpoznal jeho úmysel, obrátil sa na gazdinú s prosbou: „Dcéru pýtam! Margitu! / Tú mi dajte za ženu.“

Bottov príbeh nemá taký rozsiahly a konkrétny epický dej. Je realizovaný významovo hutnými opismi na princípe kontrastov (Miko 1976: 269-280) v správaní a konaní macochy a Margity („Vdovička pekná, mladá, / vydávat’by sa rada“). Motív „pytačov“ („vohl'ačov“) posunul Botto oproti Hviezdoslavovi do všeobecnejšej roviny („Idú, idú, vohlači: / na vdovu nik nepáči, / len sa každý hned' pýta: / A kdeže je Margita?").

V d'alšom priebehu deja Hviezdoslavova postava urazenej a poníženej mladej bohatej vdovice vyslovuje Janovi jasné „Nikdy“ s odkazom: „Hlucháñ, slepec..." Na tomto mieste sa príbeh „láme“ do svojej tragickej podoby. Macocha naplánuje pomstu - tu sa Hviezdoslav aj Botto stretli, avšak ich riešenie tragického konca je odlišné.

Hviezdoslav rieši čas pomsty „v nedel'u“: ráno vdovica „vlúdne“ oznámi Margite, že dáva súhlas na jej svadbu s Janom. Neskoro popoludní sa chystá na dážd', no macocha napriek tomu posiela Margitu do Turca, aby pozvala na svadbu „pokrevných“. Botto posúva čas Margitinej cesty do Turca po lete, pričom ju ,posiela“ len k tete, aby si u nej oddýchla po tažkej práci. Hviezdoslavov dramatický opis strastiplnej Margitinej cesty podvečernou a večernou krajinou neobsahuje nadprirodzené predstavy a živly. Osoba, ktorá ju prenasleduje a sotí „od chrbta“ z „Besnej“ do Váhu, je „zakrútená do obrusa“, čím len vzdialene pripomína „Marmurienu“, teda Morenu, staroslovanskú bohyňu smrti a zimy. Podl'a slov „šuráka“ v osobe spoznávame sokyňu v láske. Botto v tejto časti príbehu na malej ploche dvanástich sedemslabičných veršov a na princípe kontrastov stručne 
opísal dramatickú situáciu príchodu dievčiny a jej vrahyne k Váhu a vražedný

čin „vzteklice“.

Záver Hviezdoslavovej balady je, oproti Bottovej verzii, konkrétnejší: utopené dievča našiel „rybár“, prievozníci ho priniesli do domu vdovice, ktorá, aby zakryla svoj hrozný čin, predstiera utrpenie zo straty nevlastnej dcéry („,,Rata! vrieskla..."). Podobne sa správa aj na pohrebe („mat'si tajne oči slini“). Nasledujúce hl'adanie príčiny Margitinho pádu, do ktorého sa zapojí celá dedina („Vražda...?... [...] Schválny zhod?... [...] vetria, blúdia. / Až konečne dotušili..."), ukončí samotná vdovica vyznaním lásky Jánovi. Jej plán stroskotá. Začne sa jej zápas s vlastným svedomím. Prenasledovaná dedinčanmi, ,drábom“ a vlastnými výčitkami („Kvet môj, svet môj... kde si?") absolvuje svoju poslednú cestu k skalnému bralu, aby z neho „ani vták“ zletela „v rieky pažerák“.

Obidvaja básnici vystavali závery svojich balád na mravnom princípe, presnejšie na zápase macochy s vlastným svedomím, ktorý vrcholí, ako je to v lú dových alebo romantických baladických sujetoch, o polnoci. V tomto smere položil Botto oproti Hviezdoslavovi väčší dôraz na zachytenie vnútorného stavu macochy, na prežívanie jej trápenia a žial'u zo skutku, ktorý vykonala, a na jej rozhodnutie vziat' si život podobným spôsobom, ako ho ona vzala Margite (Kraus 1966: 238).

Hviezdoslavova balada Zuzanka Hraškovie (Hviezdoslav 19ooc: 449$451)^{15}$ patrí medzi čitatel'sky najznámejšie autorove diela. ${ }^{16}$ Od ostatných Hviezdoslavových balád sa líši najmä tým, že na relatívne krátkej jedenást'strofovej ploche sa odohrá psychologická dráma dvoch ženských postáv- macochy a jej nevlastnej dcéry. Hviezdoslav predstavil tento v ludovej slovesnosti známy archetyp disharmonického obrazu negatívneho a pozitívneho životného princípu kontrastným spôsobom. Macocha je v jeho predstave nespravodlivá žena, ktorá pácha zlo na neštastnej polosirote. Neusiluje sa pochopit' jej povahu, jej gestá vzdoru, jej hodnotový svet, namiesto toho presadzuje vo výchove svoj temperament. Postavu Zuzanky epicky tvaruje ako malé nevinné dievča s romantickou črtou vzdoru proti správaniu, výchovným metódam a hodnotám nevlastnej matky.

Kontrast je základným stavebným pilierom hlavných postáv sujetu, ale aj druhovej a výrazovej štruktúry a kompozície balady na makro- a mikroúrovni. Túto metódu, ktorú Jozef Hvišč výstižne pomenoval epikou v lyrickej situácii (Hvišč 1975: 166), Hviezdoslav použil v celej básni. Subjektivizácia epického princípu rozprávania je jeho špecifickým zobrazovacím nástrojom. $V$ tomto smere sa líši od romantického spôsobu zobrazovania baladického príbehu, v ktorom, naopak, dominujú lyrické výrazové dominanty, vrátane rozprávania v ja-forme.

Psychologické napätie medzi ženskými protagonistkami, ktoré sa vyhrotí nielen tým, že otec neuzná dcérine žaloby, ale najmä tým, že Zuzanka neosloví macochu slovom mama, len náznakom tohto slova (autor uviedol slovo

15 Citáty z balady sú z edície Hviezdoslav 1948a: 147-149.

16 Balada Zuzanka Hraškovie, vd'aka svojmu univerzálnemu sociálnemu vztahovému archetypu známemu najmä z rozprávkových a legendických sujetov, ale aj z príbehov ludovo a sociálno-sentimentálne zameranej literatúry (macocha - jej nevlastná dcéra, zastarane pastorkyňa), oslovila značnú čast' čitatel'skej verejnosti, bola a je súčastou dramaturgie milovníkov recitačného umenia, siahli po nej rozhlasoví a televízni tvorcovia. Osobitne treba pripomenút televízne spracovanie z roku 1991 (scenár Vincent Šikula, réžia Franek Chmiel, dramaturgia Jana Liptáková). V kontexte slovenskej literárnej histórie sa ňou zaoberali viacerí bádatelia (Hvišč 1975: 159-181; Gbúr-Sabol 2014: 145-162). 
624 mama s apostrofom: „Ubila / mam' ma...!"), nevyrieši ani „totčička“, pretože jej hnev proti správaniu macochy zostane iba vo verbálnej rovine („Len sa otrasiem, /pôjdem jej nakydat'!...").

Motív Zuzankinej návštevy hrobu jej mŕtvej matky je dôležitý pre otvorenie d'alšieho kontrastu smerujúceho k osudovému záveru. Uvedeným kontrastom je vzt'ah medzi reálnym a záhrobným svetom, ktorý je typický pre tradičnú ludovú a následne aj romantickú baladu. Hviezdoslav ho nerealizoval explicitne, ale iba v náznakovej podobe. Zuzanka nenachádza pomoc medzi živými l'ud'mi, preto sa so svojím trápením obracia na nebohú matku (oslovuje ju „mamičko“) a prosí ju o pomoc a útechu. Záhrobie však mlčí, odozva neprichádza (,mlk-smrti záhada"), kontrast medzi reálnym a záhrobným svetom sa nerealizuje, čo ukazuje na sujet realistickej balady. Na cintorín neprichádza o polnoci, ako je to zvyčajné v romantických baladách, ale v jesenný podvečer, v čase „víchrenia“, pred silným dažd'om. V triáde Zuzankinho hl'adania opory (,ňaničko“ - „totčička“ - „mamič$k a^{\text {“) }) ~ H v i e z d o s l a v ~ f u n k c ̌ n e ~ v y u z ̌ i l ~ a j ~ m i k r o k o m p o z i c ̌ n y ́ ~ p r v o k ~-~ i n t e r p u n k c ̌ n e ́ ~ z n a-~}$ mienko (pomlčku). Práve ňou ,jjednoznačne signalizoval hranicu medzi reálnym a záhrobným svetom“, pričom tento prvok umiestnil do textu priam s „matematickou presnostou“" (Gbúr - Sabol 2014:150). V prvom prípade (hladanie pomoci $\mathrm{u}$,ňaňa“) dal pomlčku za syntaktickú štruktúru („Poviem ňaňovi-.“), v druhom prípade (hladanie pomoci u „totčičky“) pomlčkami oddelil krátky syntaktický celok (,-poviem totčičke -“). V tretej časti triády pomlčku umiestnil medzi predikát a predmet (,... Poviem - mamičke..."), čím graficky vyznačil hranicu medzi reálnym a ireálnym (záhrobným) svetom.

Voda nadobúda v baladickom závere svoju sémantickú dôležitost'. Je darom pre prírodu, ale zároveň skazou pre polosirotu. Zuzanka uteká z cintorína domov, cestou si ide umyt' nohy do potoka, aby ju macocha zasa nepotrestala. „Besný prúd“ vody ju však strháva a ukončuje jej mladý život. „Jaj, umyt'nožičky! [...] vtom závrat - či poklzkom, / člup!... Vzal ho besný prúd.“ Motív nožičiek sa objaví ešte raz, v poslednej strofe, v rozprávačovom opise macochy („do očíblýska jej tých bielych nožiek pár..."), ktorá najprv zvaluje vinu za smrt' Zuzanky na prírodu - jarok („,... Jano, spiśs?... Jarok zas hučat' čut'- / Musíš ho odrazit!'“). Neskôr, v nočnom čase, ju „dobieha“ vlastné svedomie (,do duše dvojný žiar..."): donúti ju prosit' Boha o pomoc zbavit' sa duševnej bolesti, ktorú si spôsobila sama svojím nezmyselným konaním („Schovajich/,biele nožky‘,/och, Bože!..."). Psychologická dráma dvoch ženských postáv, ktoré sa usilovali presadit' svoje hodnotové videnie sveta (macocha reprezentuje tradičný model spoločenských konvencií, Zuzanka túži po humánnejšom modeli rodinných vztahov), sa síce skončil smrt'ou Zuzanky, ale súčasne sa pre macochu a dedinskú societu otvoril priestor na hĺbavejší ponor do vtedajšieho obrazu citových a medziludských vztahov. V tomto smere Hviezdoslav posunul riešenie konfliktných citových situácií v baladách k modernistickým riešeniam, ktoré rozvinula generácia symbolistov na čele s Ivanom Kraskom (Hučková 1992: 378-384, 2014: 280-302; Fordinálová 1995: 113-126).

Publikovanie balady Anča (Hviezdoslav 19ooa: $\left.495^{-502}\right)^{17}$ potešilo J. Škultétyho, ktorý bol v tom čase vo väzení v Banskej Bystrici: „Nad Ančou 
- som plakal od radosti!!! Tak mi odl'ahlo v bystrickej väzbe, tak mi bolo dobre, že 625 v slovenčine mojej [...] sa tvoria takéto diela" (Korešpondencia... 1962: 157). Od ostatných Hviezdoslavových balád sa tento baladicky ojedinelý príbeh líši najmä tematizovaním významových protipólov tanečnej zábavy a spôsobom tragického skonu protagonistky príbehu.

Kompozične je rámcovaný úvodným, stredovým a záverečným veršom, vktorých sa rozdielne hodnotí tanečná zábava (,muzika“). V prvom a stredovom verši má pozitívny význam, spája sa s relaxom, je uvolnením vášní, je to nespútaná, bujará, „bezuzdná“, „rujná“ a „rozbláznená“ zábava („Muzika! povol'a... // Muzika! svevol'a“). Posledný verš mení hodnotenie zábavy na negatívne („,Muzika! nevol'a“), pretože prináša len hnev, bolest' a súženie. Príbeh je situovaný na dedinskú tancovačku, ,tanec “v miestnej krčme, na ktorý sa najmä v čase fašiangov teší celá dedina, predovšetkým mládež. Začína sa dialógom matky s dcérou Ančou. Ovdovená matka jej vysvetluje dôvody, prečo by nemala íst' na zábavu. V jej naliehavej výpovedi („Nechod', Ančo, na ten tanec, nechod!'“) cítit’ zlú predtuchu, že sa tam dcére stane niečo zlé. Anča, na rozdiel od svojej matky, sa správa ako sebavedomé mladé dievča, ktoré rešpektuje svoj sociálny status (neúplná rodina), ale v realite života sa profiluje ako romantická hrdinka, ktorá svojou ciel'avedomostou chce dosiahnut' lepšie sociálne postavenie v dedinskej komunite. V tomto smere ju možno charakterizovat' ako dospelejší variant Zuzanky Hraškovie. Svoju ciel'avedomú povahu naplno prejaví na zábave, kde chce dokázat', že citovaná ludová pieseň o chudobnom dievčati, čo si vystojí na zábave jamu, nie je pravdivá. Svoj ciel' dostat' sa do predného radu medzi „,̌el'ad'sebevolnú“ sa jej podarí dosiahnut po polnoci, no to je zároveň čas, ked' sa jej životný príbeh bliži k svojmu fatálnemu finále. Gradáciu napätia záverečnej scény autor vytvoril prostredníctvom ubúdajúceho svetla („Dohárali sviečky, / žmúrajúce jakv hmle vspare dusnej") a opisov pudových, inštinktívnych, až prírodno-démonických reakcií tancujúcich. Mládenec Janko ju požiadal o tanec, ktorý bol nečakane divoký ako „krútňava dravá, nekonečná, dudniaca..... V tejto tanečnej „krútňave“ našla svoju smrt': prišlo jej nevol'no a po chvíli zomrela: ,,Joj!‘ zajakla Anča osinutá, / v pravej vznesúc kytku, mäčkajúc ju, /,rata! - nekrút', Janko, nekrút'! Hlava / zatáča sa-závrat-srdce moje-‘/ sklesla zápät...."

V názve balady Veštba kukučky je animálna postava-kukučka, rozšírená v slovenskom kultúrnom povedomí od čias starých Slovanov, ktorí ju zasvätili bohyni jari Vesne, a to pre jej charakteristický hlas (hlasné „kukanie“ samcov) ohlasujúci príchod jari. ${ }^{18}$ Práve tento zvuk nadobudol v ludovej kultúre tajuplný, záhadný, mysteriózny význam: stal sa základom povier o kukučom predpovedaní dížky života, zvlášt' u dievčat predpovedal čas do ich vydaja a podobne.

Táto animálna postava je v pozadí tragického príbehu mladého dievčat́a Uliany, ktorá nevzdoruje pravidlám ako Zuzanka Hraškovie alebo Katka z balady Smelá Katka či Anča z rovnomenného baladického príbehu. Naopak, pracovitá Ul'ka hlboko verí povere o magických, „proročich“ vlastnostiach kukučky, a to sa jej stane osudným. Kukučku nazýva „prorokom“, „veštkou znamenitou“, „mudráčkou“ a „bosorkou“. „Požiada“ ju o „vyveštenie“, o kol'ko rokov sa vydá („,Kol'ko mi rốčkov 

retáazi...?") a tejto kukučej veštbe potom prispôsobuje svoj život. Tragický záver Ul'kinej životnej cesty sa odohrá o tri roky, ktoré jej kukučka oznámila. Opakuje sa východisková situácia balady - zvážanie pokosenej trávy z podhorských lúk. Ul'ka prichádza po práci domov s plným „batohom“ trávy, spotená od námahy. Matke sa stažuje, že cíti bolest' v boku a má horúčku. Prizná sa, že sa napila studenej vody z potoka. Ochorie na „úložnicu“ (týfus) a zomrie. Jej smrtou sa naplnil kukučkou vyveštený čas jej vydaja, ale aj čas jej smrti. Prichádza po ňu ženích, ale nie ten, ktorého si vysnívala („popod stenu ženích [...] škaredý [...] zuby škeri"). Ul'kina matka, rovnako poverčivá ako jej dcéra, obracia svoj hnev za smrt' dcéry proti kukučke, ktorú v závere preklína: „Bodajs', kukučko! viac hlasu nevydala, / ked' si mi, ach, dcéru na smrt'zakukala..."

Sujetovú schému, ktorú často využívala romantická baladická literatúra (previnenie a následný trest), Hviezdoslav prehodnotil v balade Matúš Stolár. ${ }^{19}$ Jej tragický záver naznačil viaceré otázky z oblasti dobovej sociálnej modernizácie. Protagonista príbehu, starý Matúš Stolár, poruší tradíciou udržiavané pravidlá. Podl'a prvého z nich muž by mal držat' rok smútok za svoju nebohú ženu. Druhé tradované pravidlo v dedinskom prostredí využívajúce prirodzené biologické danosti ludského spoločenstva spočívalo v tom, že problematizovalo manželský vztah starého muža s mladou ženou. Tretie nepísané pravidlo, ktoré protagonista porušil, má krestanský a rodový podtext: súvisí s tým, ako chápe narodenie dietata (chlapca, respektíve dievčata) krestanská cirkev (ako Boží dar) a ako ho chápalo dedinské prostredie (z praktických dôvodov a čiastočne pre uspokojenie mužského ega sa viac tešilo narodeniu chlapca). Okrem osobitosti vzt'ahu viny a trestu má balada d'alšiu zvláštnost', ktorú neobsahujú ostatné básnikove balady s rovnakým motívom: svadba Stolára s druhou manželkou nemá explicitné časové určenie, do príbehu „nevstupujú “ nadprirodzené sily ani chmúrna a tiesnivá nálada či tajomnost', sujet neobsahuje „trojkový“ princíp, vyhrotený konfliktotvorný princíp, ba ani tematické kontrasty.

Pomerne jednoduchou baladickou „ilustráciou“ ludového príslovia na tému pýcha a jej dôsledky je epická báseň Jano Garazda (Hviezdoslav 1901: 1-7), ktorej výsledný umelecký tvar je problematický, nepozdával sa ani samotnému autorovi. ${ }^{20}$ Ked' ju posielal J. Škultétymu na uverejnenie do časopisu Slovenské pohl'ady, napísal: „Tu máš príspevok do Pohladov... - biednu pôvodinu čo piate č[íslo] tej kratšej epiky“ (Korešpondencia... 1962: 159). Sujet príbehu je vytvorený na princípe dvoch hodnotovo rozdielnych životných princípov. Nositel'om prvého z nich je gazda Jano Garazda, svojrázny, medzi dedinčanmi neoblúbený hospodár, ktorého pre jeho neprofesionálnu prácu („sotva i zná, čo je brázda“), pyšné a samolúbe správanie, ale najmä „odborné“ veštecké rady posmešne volajú „prorok“. Druhý životný princíp reprezentujú ostatní dedinčania, ktorí pri riešení každodenných povinností používajú osvedčený „,sedliacky rozum“. Ten občas zlyháva, najmä pri predpovedaní počasia. Ked' sa tak stane, siahajú po Božom slove, po duchovnej pomoci. V tomto príbehu sa „stretnutie“ uvedených princípov odohrá pri kosení podhorských lúk. Garazda sa vysmieva dedinčanom, ako 
neodhadli počasie pri sušení pokosenej trávy: odkazuje im, aby namiesto božích

služieb využili jeho „meteorologické“ rady. Ked' sa seno „dosúšalo“, prišla silná búrka, zničila prácu koscov a Garazdu takmer zabil blesk. Po zistení, že žije, kl'ačiac a vzpínajúc ruky k nebu vysloví vetu: „Kto poleje, ten oveje-“, ktorou naznačil, že chce urobit' pokánie a zaradit' sa medzi dedinčanov privolávajúcich v t'ažkých časoch jedinú skutočnú autoritu-Boha.

Baladicky koncipovaný príbeh Jedlica má svoju osobitost'v spôsobe zobrazenia vážneho sociálno-psychického problému človeka z vidieckeho prostredia, ktorého predobraz autor pravdepodobne našiel vo svojej advokátskej praxi pri riešení civilných sporov. ${ }^{21}$ Príbehovú líniu začne objektívny rozprávač opisom personifikovanej „jedlice“, ktorá dlhý čas stojí v strede lúky ako symbol slobody, vzdoru a prírodnej krásy. Pokojnú idylickú scénu odpočívajúcej rodiny gazdu pod jedl'ou naruší nahnevaný dedinský „,komorník“, ktorý tvárou („nôž v zraku, odulú hnusne tvár“) a drsnými slovami („Practe sa! Zrýkol, to lúka moja-“) dá majitel'ovi lúky najavo, že právo na lúku je jeho. Následne sa ukáže, že problémom „komornika“, ktorý prišiel pod Choč riešit' právny spor, je jeho zúfalá sociálna situácia vyvolaná závislost'ou od alkoholu („Pipiša si pýta pit“). Záver príbehu sa odohrá na druhý deň ráno, ked' rodina gazdu príde zvážat' seno z lúky. Je svedkom hroznej scény: „na hrubšej [„,haluzi“ - poznámka J. G.] za povraz / visí však komorník na jedli“, ktorý nesplnil svoj vlastný slub („Zaujmem pol'aň, prv neumrem“), zato poranil „dušu“ jedle („cit má i rastlina nemaly“"). Tá pod tarchou neštastnej udalosti vyschla: „Obstála v tisícich neštastí príboji; / pod obesencom však-podlahla“ a dedinčania ,slziac, ju-vyt'ali.“

Hviezdoslav často využíval postavu vdovy, ktorá bola z literárneho pohl'adu vhodným námetotvorným objektom: skomplikoval sa jej rodinný a súkromný život a jej postavenie v tradičnom prostredí určoval rad spoločenských konvencií. Príkladom je príbeh Motoličky, mladej vdovy z balady Mladá vdova, ktorý rozvíja tému odplaty za previnenie. ${ }^{22}$ Problémotvorným prvkom sujetu je previnenie matky-vdovy voči zvykoslovnému pravidlu (držaní smútku za nebohým manželom, zvyčajne jeden rok), ktoré Hviezdoslav uplatnil aj v balade Matúš Stolár. Smútok sa netýkal iba účasti na akomkolvek druhu zábavy, ale aj skoršieho vydaja vdovy za iného muža. Motolička v čase smútku nevynechá žiadny druh dedinskej zábavy (dôkazom je úvodné motto básne: „Sotva muža pochovala, / už by sa ti zabávala“), na ktorej sa nezdrži pitia alkoholu. Chce sa tiež znova vydat', nedbajúc na to, že by mala držat' smútok (vyplýva to z d'alšieho motta, ktorým začína druhá čast' balady: „Smútku doba neodstála, / už by sa ti vydávala“). Zabudla však, že dedina neodpúšta prehrešky proti spomínaným spoločenským zásadám ani to, ak sa žena-matka viac než výchove detí venuje svojim sexuálnym potrebám a alkoholu. ${ }^{23}$ Osobitnú úlohu rozprávača v texte má postava malého Janka, ktorý v čase matkinej neprítomnosti zabáva súrodencov čítaním a vlastným

21 Citáty z balady sú $\mathrm{z}$ edície Hviezdoslav 1948b: 72-77.

22 Citáty z balady sú $\mathrm{z}$ edície Hviezdoslav 1948b: 7-50.

23 Podl'a V. Turčányho možno v postave Motoličky identifikovat' Hviezdoslavovu švagrinú, ktorá po smrti svojho muža prepadla alkoholu, nestarala sa o deti, preto si ich manželia Hviezdoslavovci vzali k sebe dôvodiac, že „zolvica sa spravuje špatne, o deti nedbá, majetok mrhá...“ (Hviezdoslav v kritike a spomienkach 1954: 240). Podobnou postavou pijanky je aj matka Gábora Vlkolinského z rovnomenného básnického eposu. 
628 komentovaním známych rozprávkových príbehov o Jankovi Hraškovi, Martinkovi Klingáčovi a Ružovej Aničke. Významovo zatažená je záverečná lyrická reflexia básnika nad „pohoreliskom“, zobrazujúca vnútorný nepokoj mladej vdovy: „Našla som koštial'ky z diet'at'a, / z Janička?... Z Mišícka? / či jak sa menoval / šarvanec druhý? - Žial!' / hlúpa som trošička..."

Osobitost' balady Studnica je v tom, že problematizuje základný sociálny rozpor „chalupa - kaštiel'“ na individuálnej rovine: pôvodný kontrast vyzdvihovania mravnej čistoty ludových postáv proti mravnému úpadku panstva narúša konceptom postáv z obidvoch sociálnych vrstiev, ktoré sa vyznačujú okrem svojho reálneho sociálneho ukotvenia aj individuálnymi biologicko-psychickými vlastnostami. ${ }^{24}$ Animálne postavy-kone - aktívne nezasahujú do deja, dotvárajú dramatickú atmosféru prírodnej scenérie. Sujet balady obsahuje niekol'ko postáv, ktoré sa podiel'ajú na tvorbe povest'ového príbehu. Protagonistkou príbehu je Hana, slobodná, mladá a pekná „okáña“, dcéra chudobnej dedinskej vdovy Mary. Obidve ženy pracujú ako slúžky („člladníčky“) na dvore bohatého pána, ktorého rozprávač charakterizuje ako starého mládenca a prefíkaného zvodcu žien. Dôležitú úlohu v balade zohráva postava personálneho rozprávača („starý koniar"), ktorý nielen pútavo hovorí príbeh neštastnej Hany mladým pastierom koní, ale súčasne im implicitne predkladá svoje hodnotiace súdy o mravných posolstvách ženských postáv. Záverečná scéna zápasu Hany s vlastným svedomím, pokus zachránit' smrtel'ne poranené dieta v nezvyklom priestore - v tmavej studni a studenej vode, má výrazné znaky monodrámy, ktorá je jedinečným umeleckým počinom v slovenskej realistickej literatúre. $V$ polnočnej, dramaticky exponovanej scéne prináša dieta $\mathrm{k}$ studni, nožom ho takmer usmrtí a hodí do studne. Pri tom sa pošmykne, dostane „závrat“ a spadne do studne za dietatom. Vd'aka expresívne poňatému rozprávaniu koniara „počujeme“ jej zúfalé výkriky, plačlivé stony, „skučanie“, „škripot“, „,vreskot“" poraneného umierajúceho dietata, ,člupot“ vody a dlhé ticho (realizované neukončenou autorskou výpoved'ou), ktoré uzavrelo zápas mladej ženy s obmedzeniami dedinskej spoločnosti aj so svojím biologicko-psychickým nastavením. Treba pripomenút', že Hviezdoslav ako tvorca dramatických textov využíval uvedený typ dramaticky vyhrotených scén aj v iných textoch. Azda najznámejším príkladom je baladicky koncipovaný monológ Zuzky $\mathrm{v}$ tret'om dejstve autorovho dramatického fragmentu $\mathrm{Na} \mathrm{Luciu.}$

\section{Záver}

Hoci lyriku tvoril Hviezdoslav kontinuálne, vo forme tematických cyklov a žánrov piesňovej a deklaratívnej lyriky, po roku 1899 venoval podstatne viac pozornosti epickým žánrom, osobitne balade. Básnické úsilie uchopit transcendentno sa u neho vždy spájalo s Božím princípom. Jeho prostredníctvom sa usiloval uchopit problémovú realitu sveta, osobitne sveta dediny, jeho civilizačné defekty, zakorenenost' v konvenčných kultúrnych stereotypoch, ale aj to, ako uchopit' priestor pre hrdinov vyrovnávajúcich sa s touto realitou. Videnie náboženskej spirituálnosti realizoval na duchovnom princípe kňazského povolania (Ukaplice). Motívy posmrtného života (Krivoprísažník, Topel'ci, Pomsta mŕtvych, Smelá Katka) mu 
slúžili na prehodnocovanie ich tradičnej baladickej funkcie: hladanie racionálnej odpovede na ukončenie iracionálneho úkazu (Krivoprísažník), vyjadrenie posmrtnej spravodlivosti medzi bohatými a chudobnými (Pomsta mŕtvych), parodické ukončenie sporu medzi prirodzenostou života a absurdno-iracionálnym územím predstavivosti (Topel'ci), civilizačný vzdor proti poverovej tradícii (Smelá Katka).

Vo všetkých baladách uplatnil také zobrazovacie prostriedky, ktorými osobitne vyzdvihol epický rozmer príbehov. Dominantnú úlohu určil autorskému rozprávačovi, pričom v niektorých textoch (Mladá vdova, Studnica) posilnil autentickost' príbehu personálnym narátorom. Epickú šírku realizoval okrem digresií (spomal'ovanie epického tempa) a parentéz (spomal'ovanie epickej narácie) najmä zážitkovým rozprávaním, pestrou modalitou viet a apoziopézami, nepravidelným počtom veršov v strofách, kompozičným členením deja na úrovni strofy a verša, rôznymi typmi rýmovej organizácie verša, veršovými presahmi, „,hovorovým“ trinást'slabičným veršom s prevahou trochejského rytmu v kombinácii s kratšími sylabickými veršovými radmi a osvedčeným osemslabičným veršom s trochejsko-daktylským rytmických pôdorysom a nepravidelnou rýmovou štruktúrou. Lyrický rozmer príbehov, najmä ich baladickú atmosféru, realizoval jednak funkčnou stavbou veršovej štruktúry, ale najmä prostredníctvom expresívne, respektíve lyricky ladených opisov a komentárov. Vo väčšine svojich realisticky koncipovaných balád funkčne využil aj niektoré zo znakov baladického žánru (najmä princíp „trojitosti“, nadprirodzené javy, nočný a polnočný čas, kontrast, tragické ukončenie príbehu).

Štúdia je výstupom grantového projektu APVV-19-0244 Metodologicképostupy v literárnovednom výskume s presahom do mediálneho prostredia. Zodpovedný riešitel': prof. PhDr. Ján Gbúr, CSc. Doba riešenia: $2020-2024$.

\section{Pramene}

HVIEZDOSLAV, Pavol Országh, 1900a. Anča. Slovenské pohl'ady, roč. 20, č. 11, s. 495-502. HVIEZDOSLAV, Pavol Országh, 1900b. U kaplice. Slovenské pohl'ady, roč. 20, č. 9, s. 401-402. HVIEZDOSLAV, Pavol Országh, 1900c. Zuzanka Hraškovie. Slovenské pohlady, roč. 20, č. 10, s. 449-451.

HVIEZDOSLAV, Pavol Országh, 1901. Jano Garazda. Slovenské pohl'ady, roč. 21, č. 1, s. 1-7. HVIEZDOSLAV, Pavol Országh, 1948a. Zobranéspisy básnické.Zväzok 6. Kratšia epika, oddiel prvý. Tretie vydanie. Turčiansky Sv. Martin: Matica slovenská.

HVIEZDOSLAV, Pavol Országh, 1948b. Zobranéspisy básnické. Zväzok 7. Kratšia epika, oddiel druhý. Tretie vydanie. Turčiansky Sv. Martin: Matica slovenská.

HVIEZDOSLAV, Pavol Országh, 1948c. Zobranéspisy básnické Hviezdoslava. Zväzok 8. Kratšia epika, oddiel tretí. Tretie vydanie. Turčiansky Sv. Martin: Matica slovenská.

HVIEZDOSLAV, Pavol Országh, 1956. Kratšia epika zo života dedinského ludu. Bratislava: Slovenské vydavatel'stvo krásnej literatúry.

\section{Literatúra}

FABIAN, Anton-CHALUPA, Július, 2016. Studňa a pavučina. I. Úvahy inšpirované evanjeliom. Trnava: Spolok svätého Vojtecha. ISBN 978-80-8161-215-2.

FORDINÁLOVÁ, Eva, 1995. Slovenská psychologická balada. Slovenská literatúra, roč. 42, č. 2-3, s. 113-126. ISSN 0037-6973. 
GBÚR, Ján-SABOL, Ján, 2014. Veršv štruktúre básnického textu. Acta Facultatis Philosophicae Universitatis Šafarikianae 17. Košice: Univerzita Pavla Jozefa Šafárika. ISBN 978-80-8152-220-8.

GBÚR, Ján, 2021. Topel'ci - „najfantastickejšia“ Hviezdoslavova balada. Tvorba, revue pre literatúru a kultúru, roč. 31, č. 2, s. 32-36. ISSN 1336-2526.

HUČKOVÁ [KRŠÁKOVÁ], Dana, 1992. Žáner balady v básnickom diele Ivana Kraska. Slovenská literatúra, roč. 39, č. 5, s. 378-384. ISSN 0037-6973.

HUČKOVÁ, Dana, 2014. Modernistické variácie žánru balady. In HUČKOVÁ, Dana. Kontexty Slovenskej moderny. Bratislava: Kalligram - Ústav slovenskej literatúry SAV, s. 280-302. ISBN 978-80-8101-863-3.

HVIEZDOSLAV v kritike a spomienkach, 1954. Bratislava: Slovenské vydavatel'stvo krásnej literatúry.

HVIŠČ, Jozef, 1975. Genologická interpretácia Hviezdoslavovej balady Zuzanka Hraškovie. In P. O. Hviezdoslav. Text a kontext. Dolný Kubín: Literárne múzeum P. O. Hviezdoslava - Nitra: Kabinet literárnej komunikácie a experimentálnej metodiky Pedagogickej fakulty, 1975, s. $159-181$.

KOREŠPONDENCIA P. O. Hviezdoslava so Svetozárom Hurbanom Vajanským a Jozefom Škultétym, 1962. Na vydanie pripravil Stanislav Šmatlák. Bratislava: Veda.

KRAUS, Cyril, 1966. Slovenská romantická balada. Bratislava: Veda.

MATIAŠKA, Milan, 2001. Povaha digresie vo Hviezdoslavovej epike. Slovenská literatúra, roč. 48, č. 3, s. 185-190. ISSN 0037-6973.

MIKO, František, 1976. Romantická balada a lyrický subjekt (Pokus o výrazovú analýzu). In O interpretácii umeleckého textu. 5. Zborník Kabinetu literárnej komunikácie a experimentálnej metodiky Pedagogickej fakulty v Nitre. Bratislava: Slovenské pedagogické nakladatel'stvo, s. 269-280.

MOCNÁ, Dagmar, 2012. Transformace baladického žánru v básnické tvorbě Jana Nerudy. Slovenská literatúra, roč. 59, č. 4, s. 312-323. ISSN 0037-6973.

TURČÁNY, Viliam, 1963. Hviezdoslavova kratšia epika. In Litteraria VI. Literatúra a jazyk. Bratislava: Veda, s. 193-251.

TUREČEK, Dalibor, 2012. Několik předběžných poznámek k proměnám české balady v letech 1860 - 1918. Slovenská literatúra, roč. 59, č. 4, s. 297-311. ISSN 0037-6973.

\section{Internetové zdroje}

História kalvárie. Dostupné online: https://www.farabobrov.sk/kalvaria/historia-kalvarie/

Prof. PhDr. Ján Gbúr, CSc.

Filozofická fakulta UPJŠ

Šrobárova 2

04001 Košice

Slovenská republika

E-mail: jan.gbur@upjs.sk 